\title{
Características de expansão, diferenciação e criopreservação de células-tronco mesenquimais obtidas do líquido amniótico no segundo trimestre de gestação
}

\author{
Characteristics of expansion, differentiation and cryopreservation of mesenchymal stem cells \\ obtained from amniotic fluid in the second trimester of pregnancy
}

Felipe de Lara Janz

Orientador: Sergio Paulo Bydlowski

\section{Resumo}

As células-tronco mesenquimais (CTM) são células indiferenciadas que apresentam altas taxas de proliferação em cultivo, capacidade de diferenciação em inúmeros tecidos e podem ser encontradas no organismo adulto e, também, em tecidos fetais, como cordão umbilical, placenta e líquido amniótico (LA). Estudos demonstraram que o LA humano obtido por amniocentese no segundo trimestre de gestação, também utilizado em exames de diagnóstico fetal, apresenta-se como uma fonte em potencial destas células progenitoras. Contudo, estas células necessitam de mais estudos quanto às técnicas de isolamento, expansão e, sobretudo, acerca dos protocolos de congelamento utilizados em sua criopreservação. Neste trabalho nos propusemos a padronizar técnicas de cultivo para as CTLAs: analisar o melhor meio de cultura e densidade de inóculo; avaliar as características biológicas, tais como estado de indiferenciação, ciclo celular, marcadores de membrana, plasticidade e, ainda, testar dois protocolos de congelamento celular (padrão e gradual) com diferentes criopreservantes (DMSO, glicerol, trealose e sacarose) que mantivessem uma alta viabilidade e as demais características das células-tronco após períodos de $3 \mathrm{e}$ 6 meses de armazenamento em nitrogênio líquido. Ao fim dos experimentos constatamos ser o líquido amniótico uma rica fonte de CTMs passíveis de serem isoladas e cultivadas com meio de cultura alfa-MEM suplementado com $20 \%$ de SFB. Padronizamos a contagem celular inicial das amostras para otimizar o plaqueamento primário, uma densidade de inóculo ideal para as passagens posteriores $\left(5.000\right.$ céls $\left./ \mathrm{cm}^{2}\right)$ e o tempo de dobramento celular (cerca de 30 horas). As CTLAs expressaram genes de indiferenciação: Oct-4, Sox-2 e Nanog, positividade para marcadores de superfície CD29, CD44, CD90 e CD105, alta taxa de proliferação in vitro e diferenciaram-se em tecido ósseo, adiposo, cartilaginoso e neuronal. Não encontramos diferença entre os dois métodos de congelamento avaliados no que diz respeito à viabilidade pós-congelamento. Todos os criopreservantes analisados mantiveram o estado de indiferenciação e plasticidade das células-tronco congeladas por 3 e 6 meses; contudo, o DMSO a $10 \%$ proporcionou maiores taxas de viabilidade do que os demais. As CTLAs ficam, desta maneira, melhor caracterizadas, com protocolos de cultivo e estocagem bem estabelecidos, facilitando a produção de células-tronco funcionais em larga escala, aptas a serem utilizadas em experimentos futuros. fetais

Descritores: Criopreservação; Células-tronco; Células-tronco

\section{Abstract}

Mesenchymal stem cells are undifferentiated progenitor cells that have high proliferation rates in culture mediums, are able to differentiate into varying tissues and can be found in adult and fetal tissues including umbilical cord and placental blood and amniotic fluid. Studies have shown that human amniotic fluid obtained by amniocentesis in the second trimester of pregnancy, commonly used in fetal tests, is a potential source of progenitor cells. However, further studies are required in respect to isolation and expansion

Laboratório de Genética e Hematologia Molecular, Faculdade de Medicina da Universidade de São Paulo - USP - São Paulo (SP), Brasil.

Suporte Financeiro: Conselho Nacional de Desenvolvimento Científico e Tecnológico (CNPq) e Coordenação de Aperfeiçoamento de pessoal de Nivel Superior (CAPES) - Brasilia (DF), Brasil. 
techniques and, especially freezing protocols for cryopreservation. Thus, this study analyzed isolation and expansion methods of amniotic fluid stem cells including the culture media and inoculum density and biological characteristics such as the undifferentiated state, cell cycle, membrane markers and plasticity. Two freezing protocols (standard and graduated) were tested using different cryoprotectors (DMSO, glycerol, trehalose and sucrose) and the viability and other characteristics of the stem cells were studied after 3 and 6 months of storage in liquid nitrogen. This study showed that amniotic fluid is a rich source of mesenchymal stem cells that can be isolated and cultured with alpha-MEM medium supplemented by $20 \% \mathrm{FBS}$. The best primary inoculum for future steps was found to be 5000 cells $/ \mathrm{cm} 2$, giving a doubling time of around 30 hours. Amniotic fluid stem cells expressed the undifferentiated genes Oct-4, Sox-2 and Nanog, and were positive for the CD29, CD44, CD90 and CD105 surface markers. They presented a high in vitro proliferation rate and potential to differentiate into osteoblasts and adipose, cartilage and neuronal tissues. There was no statistically significant difference in cell viability between standard and graduated freezing protocols. All evaluated cryoprotectors maintained the basic features of the amniotic fluid stem cells including Oct-4 gene expression, surface markers and plasticity. DMSO at $10 \%$ provided higher viability rates. Amniotic fluid is a rich source of Mesenchymal stem cells with high expansion and differentiation capacity and both freezing methods can be used to store amniotic fluid cells. All the cryoprotectors tested maintain the viability of the amniotic fluid stem cells.

Keywords: Fetal stem cells; Mesenchymal stem cells; Cryopreservation

Avaliação: A RBHH publica os resumos e abstracts de teses da área apresentados em entidades que tenham programas de pós-graduação reconhecidos pelo $\mathrm{MEC/Capes} \mathrm{e} \mathrm{considera} \mathrm{a} \mathrm{obtenção} \mathrm{do} \mathrm{título}$ suficiente para sua publicação na forma como se propõe a seção. 